\title{
Phosphatidylcholine Translocator ABCB4
}

National Cancer Institute

\section{Source}

National Cancer Institute. Phosphatidylcholine Translocator ABCB4. NCI Thesaurus. Code C123864.

Phosphatidylcholine translocator ABCB4 (1286 aa, 142 kDa) is encoded by the human $A B C B 4$ gene. This protein is involved in the transport of phosphatidylcholine, organic anions and drugs. 